\title{
Research on Web-based Autonomous English Learning of Engineering Students
}

\author{
http://dx.doi.org/10.3991/ijet.v11i06.5802 \\ Shuping Yao \\ Luoyang Institute of Science and Technology, Luoyang, China
}

\begin{abstract}
-with the development of computer and internet technology, web-based autonomous learning is increasingly becoming an essential element in the learning process for college students. Web-based autonomous learning, based on humanism and constructivism, has combined autonomous learning and internet technology, and opened up a new path to college English learning. Mastering English is even more important for engineering students whose native language is not English, as many engineering graduates encounter difficulties in their English-related work. Most scientific papers or journals globally are written in English. Most engineering graphs are also marked in English. To prepare engineering students for their future careers and life-long study, research is conducted in this paper to investigate the current situation of web-based autonomous English learning of engineering students in particular and current problems in their process of learning. Based on research findings, possible solutions and suggestions are proposed to solve the problems and improve students' autonomy in English learning.
\end{abstract}

Index Terms-Web-based autonomous English learning; Engineering students; Current situation

\section{INTRODUCTION}

With the development of technology, the computer is increasingly playing an important role in people's daily lives. In the educational field, many language researchers have shifted their attention from teachers' teaching to students' learning. Web-based Autonomous English Learning (AEL) is a subject in foreign language teaching undergoing intense study, and it is gaining popularity on campuses. In order to keep up with the new development in higher education in China, deepen teaching reform, and meet the needs of society for qualified professionals in the new century, many colleges and universities are adopting the new English teaching model where internet technology is applied to assist learners' autonomous learning (Tatiana, 2016) [1].

For engineering students in particular, whose native language is not English, mastering English is even more important, not only for their academic life but also for their prospective career. Although the number of native English speakers globally is only about 380 million, it is spoken by 1.8 billion people in the world and the number is still rising. As a result, English has become an informal standard language in scientific and technical fields, including engineering. Without a good command of the language, engineering students find themselves being unable to understand the underlying concepts or ideas that the authors try to convey in their scholarly papers (K. Latha, 2014) [2]. Moreover, many engineering students are required to write academic reports in English. Hence a good grasp of English language is necessary. However, the number of class hours per week of English learning is very limited in the curriculum for non-English majors, including engineering students. Web-based autonomous English learning makes a useful supplement to traditional English teaching. It offers a large quantity of resources, breaks the constraints of time and space, and improves the students' learning abilities, especially the ability of autonomous learning in general for the personal life-long learning and development.

With the arrival of the information age, almost all college students own their own laptops and mobile devices. The university teaching buildings, dormitories and campuses are all covered with a wireless network signal, making access to the internet very convenient. However, many college students are unable to make effective use of the numerous and powerful online learning resources. Based on this situation, research is carried out to investigate the current situation and existing problems of the web-based autonomous English learning of engineering students. Furthermore, suggestions are proposed to improve engineering students' capability of autonomous English learning.

\section{LITERATURE REVIEW}

\section{A. Learner Autonomy}

Learner autonomy has been a buzz word in foreign language education in recent decades, especially in relation to lifelong learning skills. It has transformed traditional practices in the language classroom and has given rise to selfaccess language learning centers (SALC) around the world such as the SALC at Kanda University of International Studies in Japan, the Arthur Samy Language Learning Centre (ASLLC) at The Hong Kong Institute of Education, the Self-Access Center (SAC) at Hong Kong University of Science and Technology. As the result of such practices, in language learning education, teaching is now sometimes considered with equal weight as learning, and the learner has been placed in the center of attention in some places.

The term "learner autonomy" was first coined by Henri Holec. His definition, "the ability to take charge of one's own learning" (Holec, 1981) [3], provided the theoretical framework for the future research in this field. Later on, many definitions have been given to the term, depending on the writer, the context, and the level of debate to which educators have risen. Among these various definitions it has been considered as a personal human trait, or as a political or an educational activity.

Attitudes towards autonomous learning have been studied as a psychological characteristic to analyze the way 
PAPER

learners develop their autonomy (Little, 1999) [4]. A sixdimensional construct was put forward to investigate a student's attitude toward Autonomy English Learning by means of a questionnaire study (Cotterall, 1995) [5]. Gan found that a learner's attitude towards autonomous English learning might have an effect on the outcomes of language learning by the learner adopting strategies for learning. Many studies have been conducted with the goal of effectively engaging learners in autonomous learning, and improving their autonomous learning capability.

With the rapid development of computer technology and popularization of the Internet, the integration of new technology into the language learning process has been explored by researchers both inside and outside of China. However, very few studies have focused on web-based autonomous English learning of non-English majors, in particular engineering students to whom English is becoming increasingly and disparately important compared with some other non-English majors.

\section{B. Theoretical Basis}

The theoretical basis of autonomous learning is mainly humanism and constructivism. Humanists emphasize the importance of self-concept and emotional factors in learners' learning process, paying more attention to "learning", and emphasizing that the learners are the subjects of information processing and the active builders of learning, rather than passive information recipients and indoctrinated objects. Constructivists think that learners should get their knowledge not through what has been taught by teachers, but through their own active learning, exploring, discovering and constructing, and they use the necessary learning materials through the method of constructing meaning (Ning, 2015) [6]. Effective learning happens when they take stock of what they already know and then move beyond it. Autonomous learning, based on the theoretical foundations of both humanism and constructivism, takes the effect on learners into account and encourages students to take responsibility for their own learning. These theories have obviously been developed step by step and shed light on the web-based college English teaching as a combination of internet technology and modern learning theories (Alessandra, 2016)[7].

\section{RESEARCH}

This section is devoted to the methodology of the present study, mainly research questions, subjects, instruments and data collection.

\section{A. Research Background}

Currently, developing learner autonomy has been a priority for college English teaching in china. With a continuous expansion of enrollment, college English teachers always face class sizes of more than 60 or even 100 students, making attention and assistance to any individual student all but impossible In addition, English learning class hours for non-English majors are very limited. So after class, students have to learn English on their own and take more responsibility for their own learning. Under these circumstances, this study aims to carry out research from teacher-centered teaching to student-centered learning to help students improve their English learning process.

\section{B. Research Questions}

Currently, an increasing number of students own their own mobile devices and/or computers. This makes it convenient for them to surf the Internet, but as of yet have they not fully taken advantage of the vast amount of online resources for autonomous English learning. In light of this, a research project is designed to investigate the reasons behind the ineffectiveness of students' autonomous English learning. The research questions of this study are as follows:

1. What is the current situation of engineering students' using the Internet to learn English autonomously?

2. What existing problems do engineering students face in their process of web-based autonomous English learning?

3. What can be done to address the problems and improve engineering students' web-based autonomous English learning?

\section{Subjects}

The participants involved in this study are 160 engineering-major undergraduates from Luoyang Institute of Science and Technology (LIT). Among them, 156 students completed their questionnaires validly, with a response rate of $97.5 \%$. The sample consisted of 38 females and 118 males in their second year of College English study. A total of 15 students were selected to take part in interviews to help researchers develop a deeper understanding of engineering students' web-based autonomous English learning.

\section{Instruments}

In these study two instruments, questionnaires and interviews were adopted to collect data.

Part 1 is mainly a questionnaire. The questionnaire was used for quantitative data analysis, designed mainly to understand the current situation of engineering students' web-based autonomous English learning and problems they encountered in the learning process. It consisted of two sections.

Section 1 includes four items. Items 1 and 2 are basic questions, including gender, ownership of a mobile device or computer that connects users to the Internet. Items 3 and 4 are about the amount of time participants spent on the Internet each day and their purposes of learning English.

Section 2 consists of eleven items related to the investigation of the current situation of engineering students' autonomous English learning and participants' attitude toward the situation. Item 5 aimed to look into participants' motivations of learning English. Items 6, 7 and 8 focus on their attitudes toward web-based autonomous English learning. Items 9-14 were designed to investigate the engineering students' opinions and their actual webbased autonomous English learning experience. Findings may help the researcher understand the general picture of the use of the Internet for autonomous English learning among engineering students. Item 15 is related to factors affecting learner autonomy.

In this part, "yes or no" questions, "check all that apply" questions, and a five-point Likert scale are employed to measure the answers of the participants. As for a "yes or no" question, the coding system of $(1=$ yes $)$ and $(0=$ no) is used. For "check all that apply" questions, they are 
basically multiple-choice questions where respondents can check any or all options listed on the questionnaire. In terms of a five-point Likert scale, a rating scale of 1-5 is used, where 1 means "strongly disagree, 2 means "somewhat agree", 3 means "neither agree nor disagree", 4 means "somewhat agree" and 5 means "strongly agree".

Part 2 focuses on a face-to-face interviews. The interview consists of three questions and were conducted with fifteen randomly selected engineering students for qualitative data analysis, aiming at collecting in-depth information. The interview questions expand on questions from the questionnaire.

\section{E. Data Collection}

The questionnaires were distributed to students during their break times, taking about 15 minutes to complete. To ensure a quick and accurate understanding of the items, the questionnaire was written in Chinese, the participants' native language. 156 valid questionnaires were collected. After data collection, 15 out of 156 participants were randomly invited for interview in their spare time. Interviewees were allowed to speak Chinese, which makes them more comfortable to share their ideas.

\section{RESEARCH RESULTS AND ANALYSIS}

Data analysis is a description of the collected data as well as a process by which the researchers bring their own interpretation to the data. This section focuses on research results and data analysis. It provides a general picture about the current situation of web-based autonomous English learning of engineering students and current problems in the process of learning.

\section{A. Results of Questionnaires}

Section 1 of the questionnaire consisted of four items concerning gender, ownership of a mobile device or a computer that allows users to surf the Internet, time spent on the Internet and their purposes.

Item 1 is a dual-choice question about the gender of participants. As can be seen in Figure I, of all 156 participants, $75.6 \%$ are males, and $24.4 \%$ are females. This conforms to the fact that very few girls choose engineering as their major in China.

Item 2 is simply a "yes" or "no" question. According to Figure 2, 97.4\% of engineering undergraduates have their computers or mobile devices connected to the Internet, and only $2.6 \%$ cannot connect to the Internet. That is to say, almost all engineering students can use their mobile devices or computers to surf the Internet, meaning they also have the potential advantages of using online resources for autonomous English learning.

Item 3 was designed to investigate the amount of time that engineering students spend on the Internet every day. According to Figure 3, 20.5\% of engineering students spend less than 1 hour on the Internet every day, $40.4 \%$ spend $1-2$ hours, $26.3 \%$ spend $3-4$ hours, and $12.8 \%$ spend more than 5 hours on the Internet every day. This indicates that over time, students have broadened their uses of the Internet and increasingly incorporated it into their daily lives. Although many college students say they are very busy with classes arranged by their school, they manage to spare several hours a day to surf the Internet.

College students use the Internet for a wide variety of purposes, such as games, course-related work, chat or per-

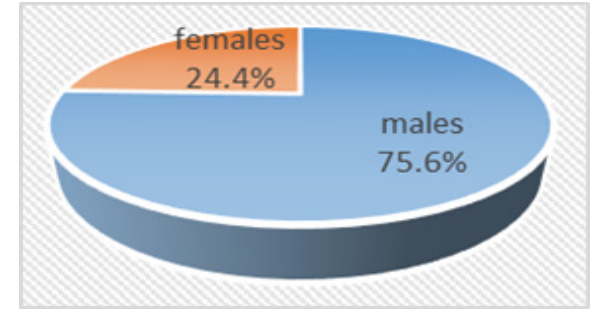

Figure 1. Gender

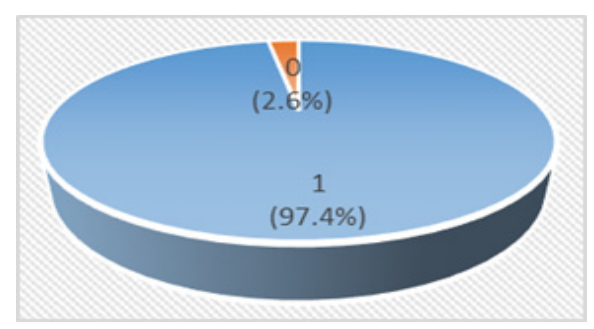

Figure 2. Access to the internet

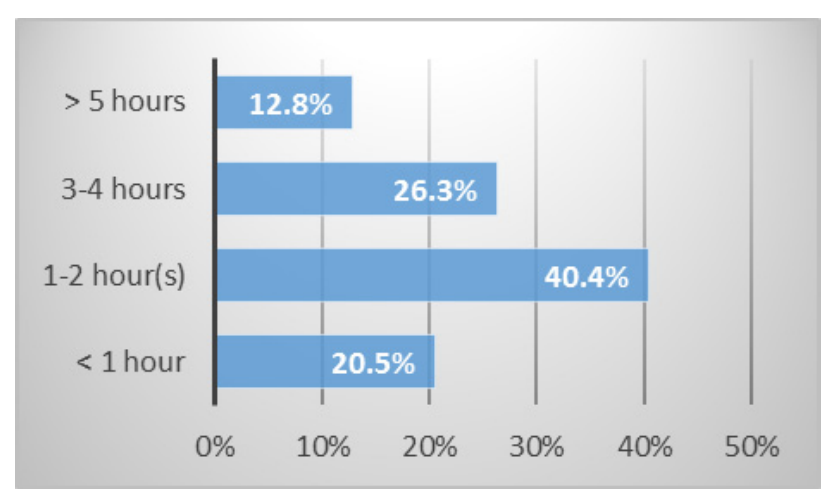

Figure 3. Time spent on the internet every day

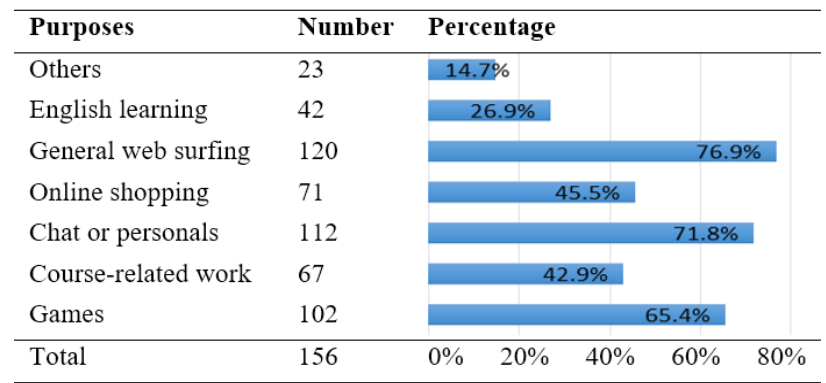

Figure 4. Purposes of using the internet

sonals, online shopping, general web surfing, English learning and other purposes. Although engineering students can connect to the Internet conveniently, they seldom use it for English learning. As is shown in Figure 4, students were asked "What are your purposes of using the Internet?" Only $26.9 \%$ of students said they use the Internet for English learning, while 76.9\% use the Internet for a general web surfing. $45.5 \%$ use the Internet for online shopping, $71.8 \%$ for chat or personals, $65.4 \%$ for games, $42.9 \%$ for course-related work, and small percentage surf the internet for other purposes. The data shows that engineering students who participated in the survey have little motivation for learning English autonomously through the internet. All in all, it is important to encourage engineering students to make full use of the Internet's capability as an aid to learning English. 
Item 5 is about students' motivation for learning English. Figure 5 shows that $80.2 \%$ of engineering students learn English as preparation for the CET 4/6 test, 15.4\% out of personal interest, and $4.4 \%$ as preparation for going abroad. That is to say, the vast majority of the students learn English simply to get a high mark on the exam. Only few engineering students learn English voluntarily. This is in accordance with the results found in Figure 4, which only $26.9 \%$ use Internet for English learning due to their low motivation.

Items 6-8 were designed to get an understanding of engineering students' attitudes toward web-based autonomous English learning. According to Figure 6, when students were asked "Do you think the web environment is useful for autonomous English learning?", 78.3\% of participants selected "Yes", $21.7 \%$ chose "No". This means that the majority of engineering students think the web environment is useful for autonomous English Learning. However, when students were asked "Do you know how to use the Internet for autonomous English learning?" more than half $(51.9 \%)$ answered "no". This means that students in the survey lack the knowledge about how to use the Internet for English learning. When they were asked "Are you willing to learn to use the Internet for AEL?", 29.5\% chose "no", but more than $70 \%$ students expressed their willingness to learn how to do web-based autonomous English learning. From the responses to Item 6-8, it can be concluded that most participants have a positive attitude toward autonomous English learning. It is encouraging to see that the majority of them are willing to learn to use the Internet for English learning even though they lack the knowledge about these learning strategies.

Figure 7 shows the engineering students' opinions on Internet autonomous English learning and their actual behavior. In Item 9, when students were asked to express their opinions on the statement "It's important to learn English autonomously" $17.9 \%$ of the students chose "strongly agree", $23.1 \%$ of the students chose "somewhat agree", $39.7 \%$ chose "neutral", and $0.3 \%$ chose "strongly disagree". From the data, it can be concluded that some students are not yet aware of the importance of autonomous English learning. Item 10 was to test participants' degree of agreement with the statement "I have a clear English learning plan." 14.7\% students chose "strongly agree", $16.7 \%$ chose "somewhat agree". This show, in total, "31.4\%" of the engineering students in the group have their own learning plans. Although it is not a very high proportion, the high passing rate of national CET-4 $(98.6 \%)$ in Luoyang Institute of Science and Technology proves that the majority of the participants learned English outside of class. Item 11 shows participants' use of the most common web-based English learning tools, such as Youdao, Baidu and other online learning tools. Given the statement, "I always use online tools to check new words and learn English." 19.2\% chose "strongly agree", 16.7\% chose "somewhat agree", 17.3\% chose "neutral", 26.2\% chose "somewhat disagree", $20.5 \%$ chose "strongly disagree". That is to say, a little less than half of the students in the group do not use online tools to check new words and learn English. As for the statement in Item 12, "I only learn English through the Internet if it is required." 19.2\% of participants chose "strongly agree", $13.4 \%$ chose "somewhat agree", $25.6 \%$ chose "neutral", $41.6 \%$ chose "somewhat disagree" and "strongly disagree". The data indicates that some students learn English autonomously

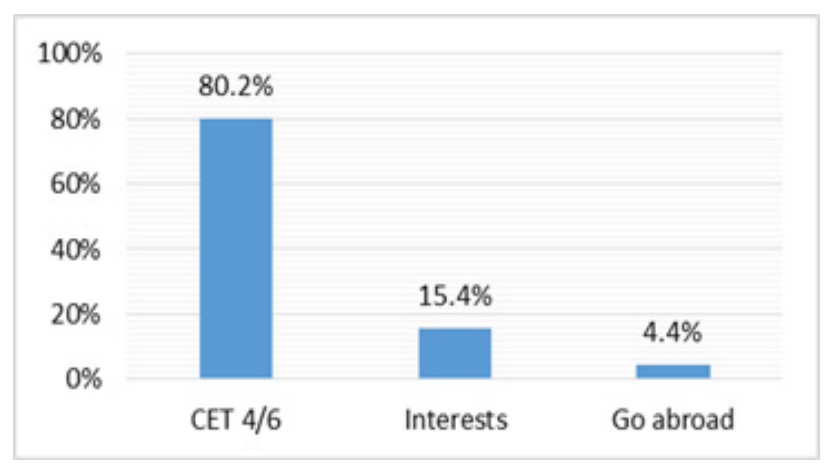

Figure 5. Motivations of learning English

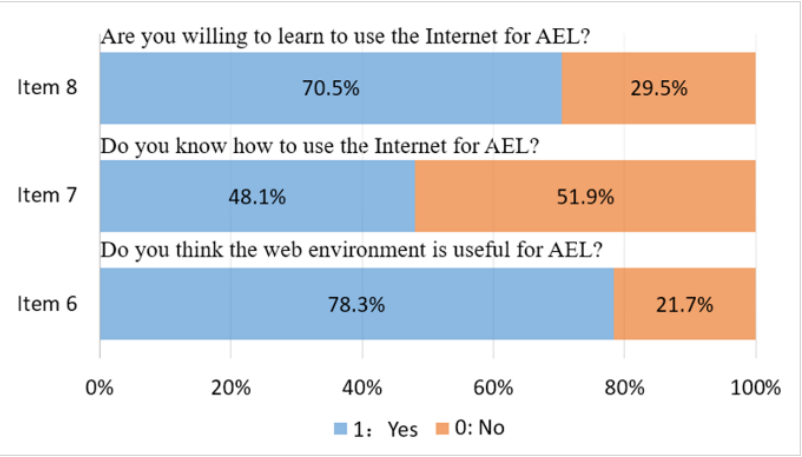

Figure 6. Attitudes toward web-based AEL

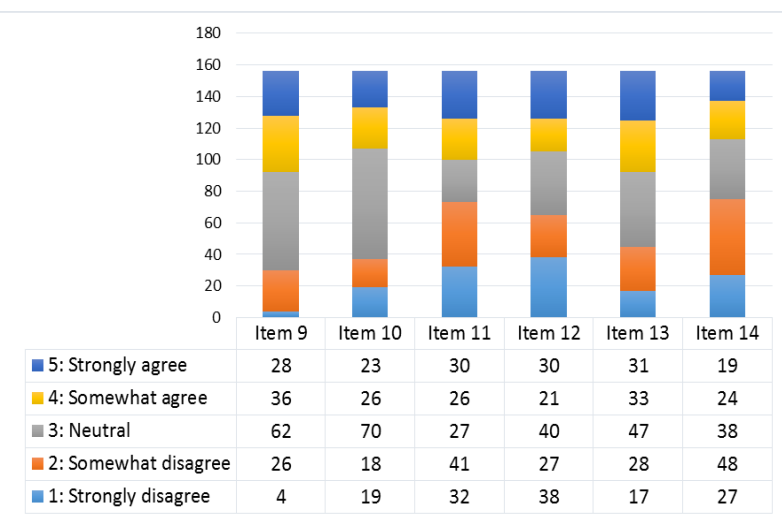

Figure 7. Opinions and actual behaviors

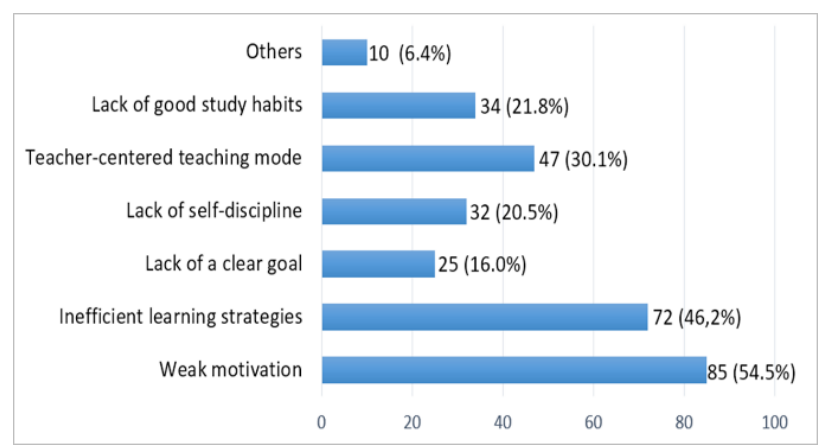

Figure 8. Factors affecting web-based AEL

through the Internet, but they lack initiative on the whole. Item 13 aims to test participants' degree of agreement with the statement "I always watch English movies for learning purposes." One important recreational activity for college students is watching movies, especially English language movies which are more attractive than Chinese 
PAPER

movies to some extent for the students. Many English majors learn English by watching English language movies. The responses to the statement in Item 13 were, 19.9\% chose "strongly agree", $21.2 \%$ chose "somewhat agree", $30.1 \%$ chose "neutral", $17.9 \%$ and $10.9 \%$ of students chose "somewhat disagree" and "strongly disagree" respectively. This means that approximately slightly more than 1/6 students surveyed watch English movies specifically for English learning purposes. For Item 14, the statement "I always visit English-learning websites to learn English" was used to test student's use of online resources for learning English. 12.2\% and 15.4\% students chose "strongly agree" and "somewhat agree", 24.3\% chose "neutral", 30.8\% chose "somewhat disagree" and $17.3 \%$ chose "strongly disagree". The data indicates that approximately half of students surveyed seldom and/or never visit English-learning websites to learn English autonomously.

Item 15 asked the students, "What factors do you think are hindering your web-based autonomous English learning?" As Figure 8 shows, Item 15 is basically a "check all that apply" question. As shown in Figure 15, 54.5\% of students surveyed attribute "weak motivation" as the major factor affecting their web-based autonomous English learning, $46.2 \%$ believe that their English learning is affected by "inefficient learning strategies", $30.1 \%$ think their learning is affected by the emphasis on traditional "teacher-centered teaching mode", $21.8 \%$ say they have not developed good study habits, $16.0 \%$ selected "lack of a clear goal", and very few students believe the factors affecting their learning are not listed here. From analysis of the data, it can be concluded that the majority of students surveyed believe that "motivation" is playing an important role in their web-based autonomous English learning. Their autonomous learning is also greatly affected by their lack of efficient learning strategies and the emphasis on the traditional teacher-centered teaching mode.

\section{B. Results of Interviews}

After analyzing data collected through the questionnaires, fifteen participants were randomly selected for a face-to-face interview in order to obtain more in-depth information and further prove the findings. The interview includes three questions. The results and analysis are as followers:

For question 1: "Do you know any web-based English learning strategies?" Students who gave a positive answer to this question shared their learning experiences with the interviewer. They reported learning English by regularly chatting with friends in English through QQ and Weixin, and checking new words with Youdao, Jinshan, Baidu and other online translating tools. Some students who gave a negative answer to this question expressed that the only purpose for them to learn English is to pass CET-4 or CET-6. These students are not interested in online learning, and they can acquire enough English learning materials to pass the test from book shops and libraries.

For question 2: "What role does your English teacher play in your web-based autonomous English learning?" Some students said that their English teachers teach in a traditional way, seldom or never talking with students about web-based autonomous learning, and only teaching according to the lesson plans, but they are kind enough to provide several hours' CET-4/6 training before the exam.
Others expressed that their English teachers are very important for their web-based autonomous English learning. These teachers always share their own experiences of web-based English learning with their students and communicate learning strategies to them both during and after class. Several students interviewed said their teachers sometimes assign them some particular topics and ask them to search for information autonomously through the Internet.

For question 3: "What suggestions do you have for improving engineering student's autonomous English learning through the Internet?" Most students interviewed agreed that their motivation for learning English autonomously should be motive. And if they do not realize the importance of learning English, or they have no interest in it, it is impossible for them to learn English autonomously. Some surveyed expected some guidance from their English teachers to help those set learning goals and develop English learning strategies. Meanwhile, almost all students surveyed believe their English teachers would help much if the teachers were willing or even required to do that.

In summary, it can be concluded that most engineering students know some English learning strategies, such as logging onto English-learning websites, watching English movies, chatting with friends through QQ Messenger and Weixin in English, using online translating tools, and so on. As for teachers, although some students say their teachers do not offer many suggestions on how to improve their web-based autonomous English learning skills, they believe their English teachers play an important role and can help much to improve their capability for autonomous English learning through the Internet.

\section{MAJOR FINDINGS}

With all the results and analysis conducted on the research, this section centers on making conclusions on the major findings. As is shown above, engineering students in Luoyang Institute of Science and Technology can surf the Internet conveniently after class, and most of them spend some time ranging from 1 to more than 5 hours each day on the Internet, but their low level of motivation determines their lack of initiative to learn English autonomously through the Internet. However, they have a positive attitude toward web-based autonomous English learning, and think it is important to learn English autonomously. They believe the web environment is useful for them to learn English. Although only a small number of engineering students are currently engaged in web-based autonomous English learning, they do utilize their own means of learning English, such as online tools, English language movies, and membership on English-learning websites, etc. Lastly, most students expressed their willingness to learn to use web-based English learning tools and expect guidance from their English teachers. In terms of the influencing factors, most engineering students believe that weak motivation, lack of efficient learning strategies and the influence of the emphasis on the traditional teachercentered teaching mode are the major factors that hinder them from web-based autonomous English learning.

\section{Possible SOLUTIONS}

Based on the major findings of this research, we have identified the main problems faced by engineering students in their process of web-based autonomous English 
learning, and they are weak motivation, lack of efficient learning strategies and emphasis on the traditional teachercentered teaching mode. To solve these problems, suggestions and possible solutions are developed as follows:

Firstly, provide a better learning environment. Many students with non-English majors, including engineering students, never or seldom communicate with their English teachers during or after class. Autonomous learning does not mean learning alone. It needs interaction and cooperation as well (Carmen, 2014) [8]. It is well known that abundant resources exist on the Internet However, navigating through these vast resources and effectively utilizing them is not an easy task. So it would be helpful to form learning teams under a teacher's guidance to improve interaction and cooperation, and further establish an effective and efficient learning environment.

Secondly, stimulate student's motivation. Learner's motivation is an essential factor affecting the learner's performance. Studies suggest that autonomous learning is closely related to learner's motivation. Based on the findings that most engineering students have low motivation to learn English autonomously through the Internet, certain measures should be taken. To stimulate their motivation, students should be made more aware of the advantages of web-based autonomous English learning through greater communication, where they can determine their own learning speed according to the English level and can enjoy more freedom in the learning process. Many students lack interest in English learning due to the confined nature of the learning materials. The content in the typical text book is designed for all the students in the school, whereas, the Internet provides a wide variety of learning materials for students to select as they see fit (SoHee Kim, 2014) [9]. To stimulate students' interests, learning materials should not be necessarily confined to text books. Newspapers, English movies, short stories and specifically engineering-related learning materials are all suitable for web-based autonomous English learning.

Thirdly, change teacher's traditional role. Many engineering students have become accustomed to the traditional mode of English teaching. They overly depend on teachers but seldom depend on themselves or show any self-initiative, which results in their poor autonomous learning ability (Jonathan, 2012) [10]. Both teachers and students should shift their consciousness about the roles they play in the learning process and transfer the larger part of the responsibility for learning from teachers to students to develop students' autonomous learning habits.

Fourthly, provide training programs. Training students in learning strategies is very important. For the purpose of leading the students to become more autonomous and more independent, it is necessary to conduct some learning strategy training for the learners. Students should be trained in computer skills to facilitate the improvement of their language skills by using the Internet or other learning tools.

\section{REFERENCES}

[1] Tatiana Krasnova, Ivan Vanushin. Blended Learning Perception among Undergraduate Engineering Students. International Journal of Emerging technologies in learning 11 (1), pp. 54-56, 2016.

[2] K. Latha. Role of English Language for Engineering Students. American International Journal of Research in Humanities, Arts and Social Sciences 7(2), pp. 122-123, June-August, 2014.

[3] Holec, Henri. Autonomy and Foreign Language Learning [M], Oxford: Pergamon Press, 1981.

[4] Little, D. Learner autonomy is more than a western cultural construct. In S. Cotterall \& D. Crabbe (Eds.). Learner Autonomy in Language Learning: Defining the Field and Effecting Change. Frankfurt: Peter Lang. pp. 11-18, 1999.

[5] Cotterall, S. Readiness for autonomy: Investigating learner beliefs. System 23: 195-205, 1995. http://dx.doi.org/10.1016/0346251X(95)00008-8

[6] Dali Ning. A pedagogical framework for web-based autonomous English learning in Chinese context from the perspective of Ecoconstructivism. Open Journal of Modern Linguistics 5: 361-369, 2015. http://dx.doi.org/10.4236/ojml.2015.54032

[7] Alessandra Ballarano, Francesco Colace, Massimo de Santo, Luca Greco. "The Postman Always Rings Twice": Evaluating ELearning Platform a Decade Later. International Journal of Emerging technologies in learning 11(2), pp. 35-42, 2016.

[8] Carmen De Pablos Heredero, Sajid Haider, Antón García Martinez. Relational Coordination as an Indicator of Teamwork Quality: Potential Application to the Success of e-Learning at Universities. International Journal of Emerging technologies in learning 9(5), pp. 67-70, 2014.

[9] SoHee Kim, Developing autonomous learning for oral proficiency using digital storytelling. Language Learning \& Technology 18(2): 20-35, 2014.

[10] Jonathan Mugan, Benjamin Kuipers. Autonomous learning of high-level state and actions in continuous environments. Transactions on Autonomous Mental Development 4(1), pp. 70-86, 2012. http://dx.doi.org/10.1109/TAMD.2011.2160943

\section{AUTHORS}

Shuping Yao is a lecturer in School of Foreign Languages, Luoyang Institute of Science and Technology, Luoyang, 471023, China. Her research interests include the applied linguistics, English language teaching, etc. (email: 303347355@qq.com)

Submitted 28 April 2016. Published as resubmitted by the author 26 May 2016. 